\title{
Social participation in the media: The dialogue of digital journalists with audiences
}

\section{La participación social en los medios de comunicación: El diálogo de los periodistas digitales con las audiencias}

\author{
Simón Peña-Fernández ${ }^{1 *}$, Jesús Ángel Pérez-Dasilva1 ${ }^{1}$, Koldobika Meso-Ayerdi ${ }^{1}$ and Ainara \\ Larrondo-Ureta ${ }^{1}$
}

${ }^{1}$ University of the Basque Country, Faculty of Social and Communication Sciences, Barrio Sarriena, 48940, Leioa, Spain.

*Correspondence: simon.pena@ehu.eus

\begin{abstract}
The emergence of social media altered the relation between journalism and the public in digital media and bequeathed the relationship a more active and collaborative role. As such, the general objective of this research is to characterise the dialogue between digital journalists and their audiences through social media and to describe how they perceive the consequences of this relationship. To this end, a survey was conducted with 73 digital journalists. The results display an ambivalent attitude on the part of the professionals regarding the use of social media as a tool for dialogue with their audiences. On one hand, they believe that using them is a priority need to maintain a fluid relationship with readers, although they mainly lean toward a majority one-way and limited use of them and believe that media managers have mainly perceived participation as a channel to garner audience loyalty and increase audiences.
\end{abstract}

Keywords: digital journalism; participation; interaction; audiences; social media.

Resumen: La aparición de las redes sociales alteró la relación entre el periodismo y el público en los medios digitales y le dio un papel más activo y colaborativo. Por ello, el objetivo general de esta investigación es caracterizar el diálogo entre los periodistas digitales y su público a través de las redes sociales y describir cómo perciben las consecuencias de esta relación. Para ello, se ha realizado una encuesta a 73 periodistas digitales. Los resultados muestran una actitud ambivalente por parte de los profesionales respecto al uso de las redes sociales como herramienta de diálogo con sus audiencias. Por un lado, consideran que su uso es una necesidad prioritaria para mantener una relación fluida con los lectores, aunque se inclinan mayoritariamente por un uso unidireccional y limitado de las mismas y creen que los responsables de los medios han percibido principalmente la participación como un canal para fidelizar y aumentar las audiencias.

Palabras clave: periodismo digital; participación; interacción; audiencias; redes sociales.

\section{Introduction}

Throughout most of the 20th century, audiences wielded a fairly limited influence on journalistic work (Singer \& Reese, 1996). The public played a subordinate role in newsrooms' daily routines (Loosen \& Schmidt, 2012), since journalists tended to not consider their opinion 
when deciding what became news out of fear that this would affect journalistic quality (Gans, 1979). Journalists especially trusted in their own criteria, their boss' criteria, and their professional colleagues' criteria when selecting the stories to tell (Reinemann, 2008; Deuze, 2008), and listened to their audiences' opinions to a much lesser extent (Boczkowski, 2010).

The emergence of the Internet and social media altered the relation between journalism and the public in digital media and bequeathed the relationship a more active and collaborative role (Tandoc, 2014). The classic distinction between broadcasters and recipients gave way to what Loosen and Schmidt (2012) called "empowered networks," meaning audiences that produce and share information in an active and collaborative way with the aid of digital media.

Indeed, technology has facilitated new ways of interacting with content and with the public, and one of the most-used instruments to this end are social media (Mourao \& Chen, 2020; Hedman, 2020). The uses of social media in journalism are many. Journalists use them to conduct routine tasks such as collect information, contact sources, and find ideas for new stories (Bruno, 2011; Paulussen \& Harder, 2014; Weaver \& Willnat, 2016; Rauchfleisch et al., 2017; Von-Nordheim et al., 2018), but also to connect to audiences and their professional colleagues (Powers \& VeraZambrano, 2018) and quickly obtain information (Moon \& Hadley, 2014). Social media are also useful to show public opinion (McGregor, 2019; Dubois et al., 2020), especially after mediatic events. Journalist use of social media is widespread, and they value them because they increase their professional resources (Hernández-Fuentes \& Monnier, 2020; Jaraba et al., 2020).

Amongst the different platforms in existence, Twitter has been the focus of a large part of the research, given its close relationship to journalism (Lasorsa et al., 2012; Vis, 2013; Parmelee, 2013; Swasy, 2016; Molyneux et al., 2018), although the journalistic use of others has also been studied, such as Instagram (Larsson, 2018; Vázquez-Herrero et al., 2019; Hermida \& Mellado, 2020) and YouTube (Paulussen \& Harder, 2014; Al Nashmi et al., 2017; Djerf-Pierre et al., 2019; Lopezosa, Orduña \& Pérez, 2020). The most popular social media platform, Facebook, has also drawn interest in academic research, both how journalists use it as a professional medium (Jordaan, 2013) and how it alters the way that users consume news (Somaiya, 2014; Brake, 2017; Carlson, 2018).

For journalists, the use of social media has been integrated into their professional practise (Beckers \& Harder, 2016; Bossio, 2017), despite the persistent concern over the impact that the haste and logic in real time of social media platforms might have on the quality of journalistic coverage (Bruns \& Nuernbergk, 2019).

Social media are an excellent opportunity for media professionals to self-promote since it makes it possible for them to grow their popularity and "personal brand" independently from the news organisation (Molyneux \& Holton, 2015; Roberts \& Emmons, 2016; Jukes, 2019); in fact, many media professionals are present on social media, and are even famous for using them (Ausserhofer \& Maireder, 2013).

Social media not only provide great opportunities for journalism, acting as platforms for following, obtaining, and sharing news, and even to debate current news contents (Doval, 2014). They also create multiple changes, since younger audiences now use more online and social media as their main sources of information (Newman et al., 2017).

In this regard, it would appear logical to think that journalists go where their potential audiences are, in an attempt to connect to them (Nölleke et al., 2017) and to maintain direct contact in shared spaces (Singer, 2013). Thus, digital social media not only strengthen participation in the news process; they also provide new relationships that change author structures. For example, the relationship between the news producer and the consumer changes, questioning the journalist's institutional power as a professional who decides what is news-worthy or credible (Hermida, 2012). Social media systems like Twitter and Facebook have even been described as ambient journalism, where news becomes fragmented and omnipresent, constructed both by journalists and by audiences (Burns, 2010; Hermida, 2010). 
The audience has been invited to collaborate with the media by preparing and contributing their own content (Guallar, 2007), although this new relationship between the media and audiences is not always viewed in a good light by journalists, even though it was driven by journalistic companies (Domingo et al., 2008; Singer, 2010). Some professionals are aware of the huge possibilities offered by social media, although some are also critical of any initiative that modifies their role as gatekeeper and that alters pre-existing routines and values (Wardle \& Williams, 2010; Netzer et al., 2014).

Social media have often been viewed as a way to contest the hegemony of the media, insofar as they divert participation from platforms controlled by the media to environments outside them (Masip et al., 2015). However, at the same time, they arise as an interesting tool for the media, given that they provide for sharing content and fomenting interaction (Peña-Fernández et al., 2016).

In the past twenty years, the media system has grown much more complex. This is mainly a result of technological, organisational, professional, economic, social, and cultural factors, which has led to a reformulation of the role of informers themselves (Chadwick, 2013). Throughout this reconfiguration process, many other factors pushed a revision of traditional work models, including a crisis in the business model and a critical economic situation that caused a gradual decrease in income and reduced staff. With smaller and smaller audiences, uniformity of content and credibility were jeopardised (Suau, 2015).

Within this context, the relationship between journalism and its audience underwent a great transformation, which is no trivial matter insofar as the audience is mandatory for the existence of journalism. With the drain of readers and lost income, the media took different measures, most of them aimed at retaining audiences through entertainment, but few of them were designed to draw the audience by regaining their trust (Masip, 2016).

Some studies consider the relationship between journalists and the audience as positive and desirable (Klinger \& Svensson, 2015). In the same fashion, it has been understood that the public wants to participate, wants to produce content, and wants to share it with journalists (Jenkins \& Carpentier, 2013). However, different pieces of research have proven that greater opportunities for interaction do not necessarily translate to a greater commitment and identification of the audience with the media (Peters \& Witschge, 2015). In the same fashion, other studies have shown that audiences are less active than imagined (Guallar et al., 2016), especially when participation requires a greater degree of commitment.

In this circumstance, it is relevant to know what the audience expects from its interaction with journalists, and vice-versa. Social media are becoming spaces where citizens with different worldviews can interact, and where information flows without the constraints of traditional media. In the new public digital sphere, platforms not only become a space for debate, but also facilitate reconfiguration of the media agenda (Goode, 2009). The audience takes on full prominence in the news process. Not as producer, but as gatekeeper, insofar as the users are the ones who determine interest in a news piece and the suitability of raising its visibility with a tweet or a like (Masip, 2016).

We must still elucidate whether journalists and users will be able to build a community (Picone et al., 2016), and if the former will be able to become catalysts for this public sphere of exchange and debate. Additionally, it is interesting to go further in depth as to what professionals expect from their interaction with the audience through social media. Based on this knowledge, it will be possible to establish a new relationship between the both of them, a relationship closer to what Lewis et al. (2013) call reciprocal journalism, meaning how journalists and audiences can develop reciprocal relationships that are beneficial to all.

Within this context, the general objective of this research is to characterise the relation between digital journalists and their audiences through social media and to describe how they perceive the consequences of this relationship. Based on this general objective, this research sets forth the following research questions: 
- $R Q 1$ : What are the tools that digital journalists use to dialogue with their audiences?

- $R Q 2$ : What are the reasons for digital journalists to conduct this dialogue?

- RQ3: What are the benefits and risks perceived by professionals in establishing this relationship?

\section{Methodology}

This study includes the results from a survey conducted with 73 digital journalists who work in the Basque Country, both in digital editions of conventional media and in native digital media or managing social media. To this end, they were sent a closed questionnaire on work in the digital media that considered the most recent studies on the profession (Palacio-Llanos, 2018; Weaver et al., 2019).

The initial sample was drawn up based on the Basque Government's Open Communication Guide (https://gida.irekia.euskadi.eus). This guide includes a complete listing of Basque news media and their managers. The sample was completed with the collaboration of the Basque Journalists' Association (Pérez Dasilva et al., 2021), and sought balance between men and women. The number of digital journalists, including digital edition, native media, and social media workers, accounted for $14 \%$ of all journalists in any type of media.

Surveys were conducted between 12 April and 24 May 2020. It should be noted that conducting these surveys was conditioned by the health crisis and confinement of the population declared by the Basque Government on 14 March to fight the pandemic. This was the reason why the methodology finally used was an online survey with telephone support.

\section{Results}

\subsection{Tools for dialogue with audiences}

If we analyse the tools most used by digital journalists in their daily work, the first two (telephone and email) probably do not differ much from those most used in many other professions (Figure 1). On the other hand, a particular trait that does stand out is the intensive use of social media and messenger services (Twitter, WhatsApp, YouTube, and Facebook) with almost identical intensity.

Figure 1. Digital work tools (total use/dialogue with audiences).

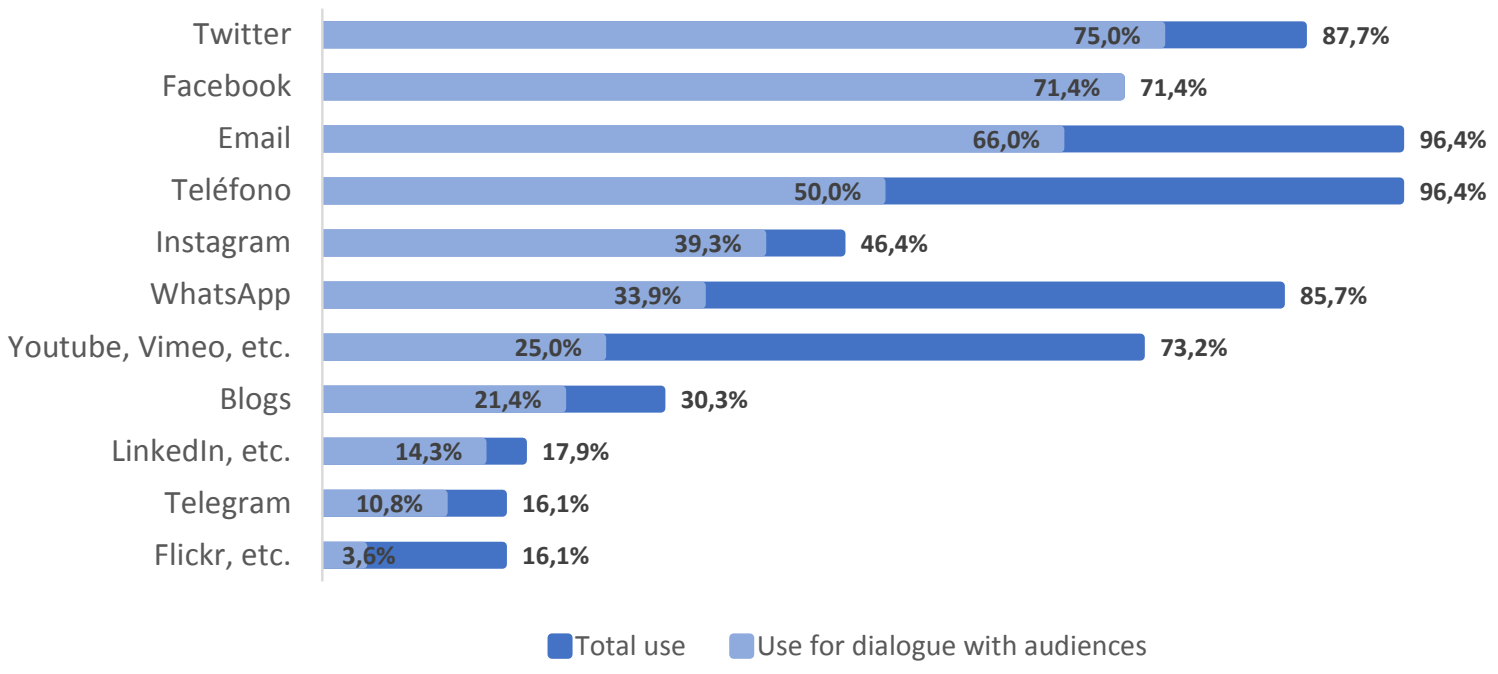

Source: Compiled by authors. 
These four platforms and tools now definitely form a part of the essential repertoire of resources to practise the journalist profession online. These data are corroborated by the very opinion of journalists themselves, given that $83.5 \%$ of the surveyed professionals ( $n=61$ ) believe that knowing how to work with social media is an essential skill for journalists today, and all of them stated that they had at least one active profile on social media. Regarding their use, $23.6 \%$ $(n=13)$ state that they use social media only for professional reasons, as opposed to $72.7 \%(n=40)$ who blend personal with professional use.

If, on the other hand, we observe which of those tools they use for dialogue with audiences, the two main social media networks stand out above the rest, with Twitter in the lead (75\%, $n=42)$, followed very closely by Facebook $(71.4 \%, n=40)$. The strong relationship between the percentage of general use and specific use for dialogue with audiences indicates that its heavy use amongst digital journalists indeed bears the purpose of getting close to readers, in addition to others.

If we delve a bit further into this aspect, the responses of digital journalists regarding reasons to use social media cast a bit more light (Figure 2). Indeed, a bit more than two out of every three professionals $(n=58)$ state that the relationship with audiences is one of the reasons that they use social media.

Figure 2. What do you use social media for in your day-to-day work?

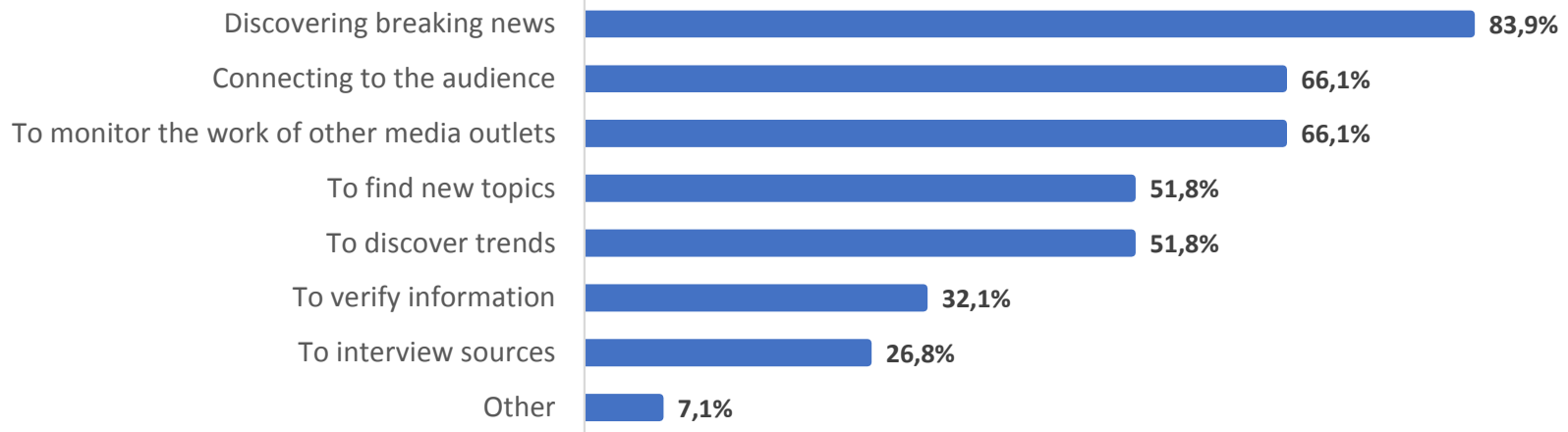

Source: Compiled by authors.

However, their use as a breaking news source $(83.9 \%, n=56)$ and to follow news published by other media outlets $(66.1 \%, \mathrm{n}=58)$ bears equal or greater relevance for professionals. As such, social media are relevant tools for relationships with audiences, but their main use is for following breaking news.

At a third level, and with slightly less relevance, journalists state that they use social media as a source for ideas and to discover trends to create their news pieces. In this case, the professionals' opinion is a bit ambivalent, given that almost half of them $(46.6 \%, n=34)$ believe that this practise jeopardises the quality of contents published by the media.

\subsection{Reasons for dialogue with audiences}

If we leave other kinds of functions behind and specifically focus on using social media to connect to audiences, the surveyed journalists state that the news media for which they work actively encourage their professionals to participate in this activity. $58.9 \%(n=43)$ of those surveyed confirm that their company encourages them to actively interact with their audience, and $43.8 \%$ confirm that the media outlet they work for has a protocol or specific guidelines $(n=24)$ to do so. As such, dialogue with audiences is increasingly an institutionalised task, and not merely a personal option for journalists.

On the other hand, professionals generally have a critical view of this task, given that only a bit more than one out of every three journalists (Figure 3) believe that their media outlet's main reason is to truly dialogue with audiences $(36.2 \%, n=21)$. In fact, most of those surveyed state that 
these policies actually seek corporate objectives, such as gaining audience loyalty or creating a community around the media outlet, in addition to bolstering its image and increasing the number of visitors. As such, the objectives perceived by the professionals have more to do with corporate strengthening of the outlet than an actual desire for dialogue.

Figure 3. What do you think your media outlet's main reason is for interacting with the audience?

To garner audience loyalty

To create community

To bolster the media outlet's image/reputation

To increase the number of visits

To encourage dialogue with the audience

Other

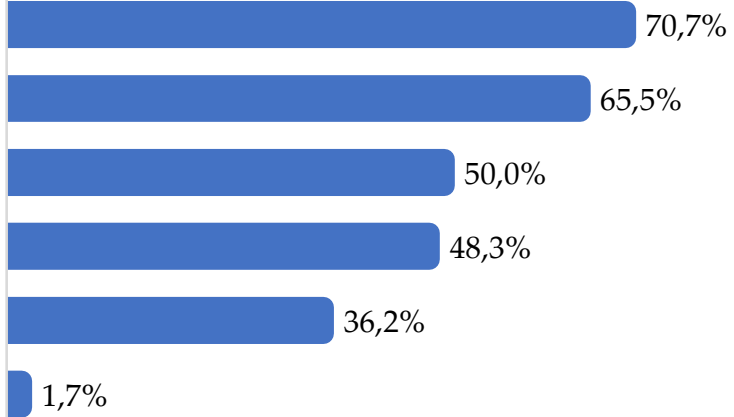

Source: Compiled by authors.

In general, journalists also display limited willingness to actively participate with audiences and prioritise interaction channels that are more one-way and not so much for dialogue. Thus, if we analyse how these social media are regularly used, practically all of them entail sporadic, oneoff contact with the audience.

Firstly, the most customary activity on social media in their relationship with readers is to trawl for new topics to address, which is mentioned by two out of every three journalists (Figure 4). After this, frequencies are significantly reduced, and all uses mentioned display limited twoway communication, such as correcting errors or broadening content included in the news pieces. To the contrary, the two options with the greatest amount of dialogue, meaning answering reader questions or asking for their opinion, are used by a bit fewer than one out of every three digital journalists $(31.5 \%, \mathrm{n}=23)$.

Figure 4. In your direct relationship with audiences, what do you use social media for?

To get ideas for new topics

To correct errors

To share additional research

To answer reader questions

To collect opinions

Other

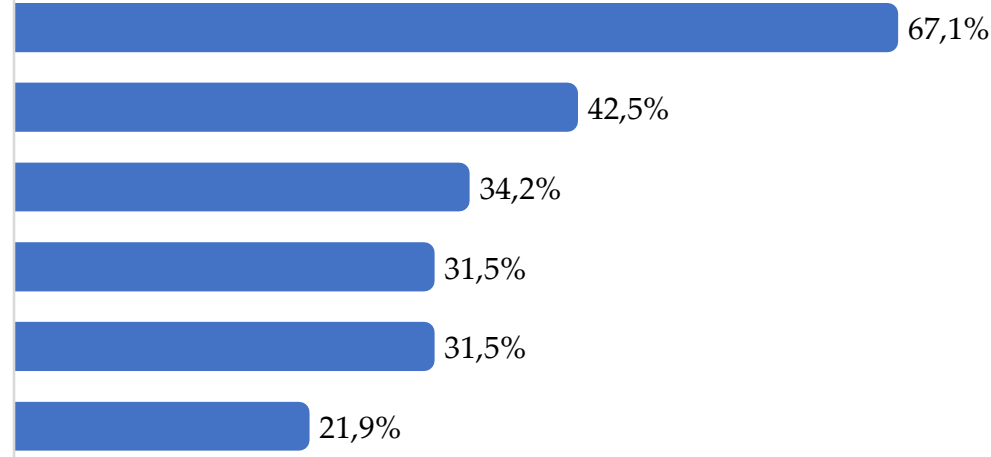

Source: Compiled by authors. 


\subsection{Perceived benefits and risks}

As a whole, two out of every three digital journalists perceive that work with social media has increased how fast they must complete their work, which jeopardises the precision of their task (Figure 5). One out of every two professionals also believes that social media pose a threat to the quality of information, and a bit more than one out of every three even believe that social media place traditional journalism values in peril.

Some of the newest and most specific risks include $61.8 \%(n=34)$ believing that social media make them more exposed, which can lead to situations of readers pressuring or harassing them.

Regarding how to manage the relationship with readers, traditional professional values are once again dominant. In this vein, practically all of the surveyed parties $(91.8 \%, \mathrm{n}=67)$ believe that quality content helps to garner audience loyalty, as opposed to $35.6 \%(n=26)$ who believe that readers are lost because they are not addressing topics of their interest.

A large majority is also of the opinion that relationships with audiences are a need for media and, in turn, one of the greatest challenges they face today.

Figure 5. What are the threats posed by social media to the journalist profession?

They sacrifice precisions for the sake of speed

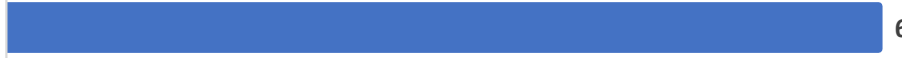

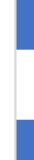

They threaten the quality of journalism

They jeopardise traditional journalist values

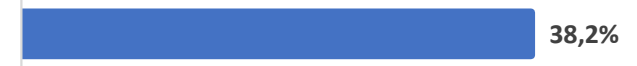

Source: Compiled by authors.

Additionally, a significant number of professionals acknowledge that they lack the skills necessary to connect to readers $(45.2 \%, \mathrm{n}=33)$, and only one out of every four states that this task takes time away from the work they must complete.

Figure 6. Rate how much you agree with the following statements regarding the relationship of media outlets with their audiences.

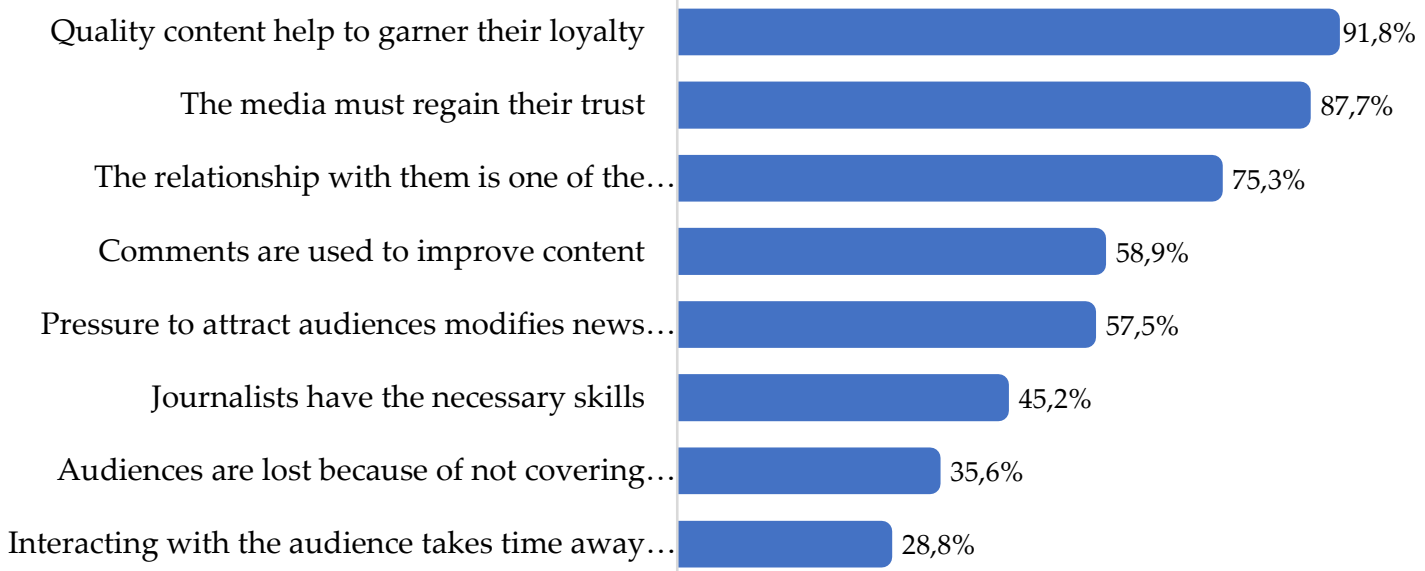

Source: Compiled by authors. 
Lastly, only one out of every three individuals surveyed $(32.9 \%, \mathrm{n}=24)$ believes that audiences should more actively participate in creating news contents.

\section{Discussion and conclusion}

The study of digital journalist opinions on their relationship with audiences through social media provides an ambivalent view. On one hand, online media professionals in the Basque Country almost unanimously identify maintaining a fluid relationship with readers and regaining their trust as a priority need. In addition, social media platforms, particularly Twitter and Facebook, are the main tools for holding this dialogue. However, even though journalists acknowledge that their companies encourage them to actively interact with their readers, and even offer them guidelines to do so, they state that the reasons behind these policies are mainly commercial and corporate.

In this regard, the responses obtained highlight the idea that media employees believe that their managers view participation as a channel to generate website traffic, to make users invest more time on the media, and to obtain greater loyalty to the publication (Vujnovic, et al., 2010; Singer, et al., 2011; Manosevitch \& Tenenboim, 2017).

The doubts in the corporate sphere also spread to professional practise. The study shows that digital journalists especially opt for mainly one-way, limited uses of existing communication channels. While problematic management of audience-generated content led to limitation on the spaces for participation in news media outlets, the force of social media naturally moved debate regarding media content and dialogue with audiences to these platforms (Masip et al., 2019). Social media are a suitable avenue to receive ideas and opinions and to find topics, but not to establish dialogue with readers (Suárez-Villegas, 2017). Journalists are willing to correct formal errors or data, but do not want interference in their editorial decisions (Pérez-Díaz et al., 2020).

Therefore, audience participation has not led to a change in journalists' view of their professional role. As Deuze and Witschge (2018) point out that it's a challenge to consider journalism as a networked practice while recognizing the permanence of meaning-giving structures, such as the newsroom. In this regard, basque digital journalists consider that the essence of journalistic work has not changed, and reassert the profession's traditional values (Örnebring, 2013; Andersson \& Wiik, 2013). Only a small portion of the professionals surveyed believe that audiences should have a more active role in news creation, so we may consider that they perceive participation in the media as mainly complementary in nature (Neuberger \& Nuernbergk, 2010; Vos \& Ferrucci, 2018).

\section{References}

Al Nashmi, E., North, M., Bloom, T., \& Cleary, J. (2017). Promoting a global brand: A study of international news organisations' YouTube channels. The Journal of International Communication, 23(2), 165-185. https://doi.org/10.1080/13216597.2017.1300180

Andersson, U., \& Wiik, J. (2013). Journalism Meets Management. Journalism Practice, 7(6), 705-719. https://doi.org/10.1080/17512786.2013.790612

Ausserhofer, J., \& Maireder, A. (2013). National politics on Twitter: Structures and topics of a networked public sphere. Information, Communication $\mathcal{E} \quad$ Society, 16(3), 291-314. http://doi.org/10.1080/1369118X.2012.756050

Beckers, K., \& Harder, R. (2016). “Twitter just exploded”: Social media as alternative vox pop. Digital Journalism, 4(7), 910-920. https://doi.org/10.1080/21670811.2016.1161493 
Boczkowski, P. J. (2010). The divergent online news preferences of journalists and readers. Communications of the ACM, 53, 24-26. https://doi.org/10.1145/1839676.1839685

Bossio, D. (2017). Journalism and social media: Practitioners, organisations and institutions. Palgrave Macmillan.

Brake, D.R. (2017). The invisible hand of the unaccountable algorithm: How Google, Facebook and other tech companies are changing journalism. In T. Jingrong \& L. Shih-Hung (Eds.), Digital Technology and Journalism (pp. 25-46). Palgrave Macmillan. https://doi.org/10.1007/978-3-319-55026-8_2

Bruno, N. (2011). Tweet first, verify later? How real-time information is changing the coverage of worldwide crisis events. Reuters for Institute the Study of Journalism. https://nicolabruno.files.wordpress.com/2011/05/tweet_first_verify_later2.pdf

Bruns, A., \& Nuernbergk, C. (2019). Political journalists and their social media audiences: New power relations. Media and communication, 7(1), 198-212. http://dx.doi.org/10.17645/mac.v7i1.1759

Carlson, M. (2018). Facebook in the news: Social media, journalism, and public responsibility following the 2016 trending topics controversy. Digital journalism, 6(1), 4-20. https://doi.org/10.1080/21670811.2017.1298044

Chadwick, A. (2013). The hybrid media system: Politics and power. Oxford University Press.

Deuze, M. (2008). The changing context of news work: liquid journalism and monitorial citizenship. International Journal of Communication, 2(5): 848-865.

Deuze, M., \& Witschge T. (2018). Beyond journalism: Theorizing the transformation of journalism. Journalism, 19(2), 165-181. https://doi.org/10.1177/1464884916688550

Djerf-Pierre, M., Lindgren, M., \& Budinski, M. A. (2019). The role of journalism on YouTube: audience engagement with 'Superbug' reporting. Media and Communication, 7(1), 235-247. http://dx.doi.org/10.17645/mac.v7i1.1758

Domingo, D., Quandt, T., Heinonen, A., Paulussen, S., Singer, J.B., \& Vujnovic, M. (2008). Participatory journalism practices in the media and beyond. An international comparative study of initiatives in online newspapers. Journalism practice, 2(3), 326-342. http://dx.doi.org/10.1080/17512780802281065

Doval, M. (2014). Spanish and Portuguese journalists on Twitter: best practices, interactions and most frequent behaviors. Observatorio, 8(3), 169-182. https://doi.org/10.15847/obsOBS832014730

Dubois, E., Gruzd, A., \& Jacobson, J. (2020). Journalists' use of social media to infer public opinion: The citizens' perspective. Social science computer review, 38(1), 57-74. https://doi.org/10.1177/0894439318791527

Gans, H. (1979). Deciding What's News. Pantheon Books.

Goode, L. (2009). Social news, citizen journalism and democracy. New Media E Society, 11(8), 1287-1305. http://dx.doi.org/10.1177/1461444809341393

Guallar, J. (2007). La renovación de los diarios digitales: rediseños y web 2.0. El profesional de la información, 16(3), 235-242. https://doi.org/10.3145/epi.2007.may.08

Guallar, J., Suau, J., Ruiz-Caballero, C., Sáez, A., \& Masip, P. (2016). News' redissemination and public debate on social networks. El profesional de la información, 25(3), 358-366. http://dx.doi.org/10.3145/epi.2016.may.05

Hedman, U. (2020). Making the most of Twitter: How technological affordances influence Swedish journalists' self-branding. Journalism, 21(5), 670-687. https://doi.org/10.1177/1464884917734054

Hermida, A. (2010). Twittering the news. Journalism Practice, 4(3), 297-308. https://doi.org/10.1080/17512781003640703 
Hermida, A. (2012). Social journalism: Exploring how social media is shaping journalism. The handbook of global online journalism, 12, 309-328. https://doi.org/10.1002/9781118313978.ch17

Hermida, A., \& Mellado, C. (2020). Dimensions of social media logics: Mapping forms of journalistic norms and practices on Twitter and Instagram. Digital Journalism, 8(7), 864-884. https://doi.org/10.1080/21670811.2020.1805779

Hernández-Fuentes, A., \& Jaraba, A. (2020). Twitter as a Source of Information? Practices of Journalists Working for the French National Press. Journalism Practice, 1-18. https://doi.org/10.1080/17512786.2020.1824585

Jaraba Molina, G., Tejedor Calvo, S., \& Cervi, L. (2020). Análisis de las temáticas y tendencias de periodistas españoles en Twitter: contenidos sobre política, cultura, ciencia, comunicación e Internet. Cuadernos.info, 47, 111-137. http://dx.doi.org/10.7764/cdi.47.1773

Jenkins, H., \& Carpentier, N. (2013). Theorizing participatory intensities: A conversation about participation and politics. Convergence, 19(3), 265-286. http://dx.doi.org/10.1177/1354856513482090

Jordaan, M. (2013). Poke me, I'm a journalist: The impact of Facebook and Twitter on newsroom routines and cultures at two South African weeklies. Ecquid Novi: African Journalism Studies, 34(1), 21-35. https://doi.org/10.1080/02560054.2013.767421

Jukes, S. (2019). Crossing the line between news and the business of news: Exploring journalists' use of Twitter. Media and Communication, 7(1), 248-258. http://dx.doi.org/10.17645/mac.v7i1.1772

Klinger, U., \& Svensson, J. (2015). The emergence of network media logic in political communication: A theoretical approach. New Media \& Society, 17(8), 1241-1257. http://dx.doi.org/10.1177/1461444814522952

Larsson, A. O. (2018). The news user on social media: A comparative study of interacting with media organizations on Facebook and Instagram. Journalism studies, 19(15), 2225-2242. https://doi.org/10.1080/1461670X.2017.1332957

Lasorsa, D. L., Lewis, S. C., \& Holton, A. E. (2012). Normalizing Twitter: Journalism practice in an emerging communication space. Journalism studies, 13(1), 19-36. https://doi.org/10.1080/1461670X.2011.571825

Lewis, S. C., Holton, A. E., \& Coddington, M. (2013). Reciprocal journalism: A concept of mutual exchange between journalists and audiences. Journalism Practice, 8(2), 229-241. http://dx.doi.org/10.1080/17512786.2013.859840

Loosen, W., \& Schmidt, J. H. (2012). (Re-) discovering the audience: The relationship between journalism and audience in networked digital media. Information, Communication $\mathcal{E}$ Society, 15(6), 867-887. https://doi.org/10.1080/1369118X.2012.665467

Lopezosa, C., Orduña-Malea, E., \& Pérez-Montoro, M. (2020). Making video news visible: Identifying the optimization strategies of the cybermedia on YouTube using web metrics. Journalism practice, 14(4), 465-482. https://doi.org/10.1080/17512786.2019.1628657

Manosevitch, I., \& Tenenboim, O. (2017). The Multifaceted Role of User-Generated Content in News Websites: An analytical framework. Digital Journalism, 5(6), 731-752. https://doi.org/10.1080/21670811.2016.1189840

Masip, P. (2016). Investigar el periodismo desde la perspectiva de las audiencias. El profesional de la información, 25(3), 323-330. http://dx.doi.org/10.3145/epi.2016.may.01

Masip, P., Guallar, J., Suau, J., Ruiz-Caballero, C., \& Peralta, M. (2015). News and social networks: audience behavior. El profesional de la información, 24(4), 363-370. https://doi.org/10.3145/epi.2015.jul.02

Masip, P.; Ruiz-Caballero, C.; \& Suau, J. (2019). Active audiences and social discussion on the digital public sphere. Review article. El profesional de la información, 28(2), e280204. https://doi.org//10.3145/epi.2019.mar.04 
McGregor, S. C. (2019). Social media as public opinion: How journalists use social media to represent public opinion. Journalism, 20(8), 1070-1086. https://doi.org/10.1177/1464884919845458

Molyneux, L., \& Holton, A. (2015). Branding (health) journalism: Perceptions, practices, and emerging norms. Digital Journalism, 3(2), 225-242. http://doi.org/10.1080/21670811.2014.906927

Molyneux, L., Holton, A., \& Lewis, S. C. (2018). How journalists engage in branding on Twitter: Individual, organizational, and institutional levels. Information, Communication $\mathcal{E}$ Society, 21(10), 1386-1401. https://doi.org/10.1177/1940161219882653

Moon, S. J., \& Hadley, P. (2014). Routinizing a new technology in the newsroom: Twitter as a news source in mainstream media. Journal of Broadcasting $\mathcal{E}$ Electronic Media, 58, 289-305. http://doi.org/10.1080/08838151.2014.906435

Mourao, R. R., \& Chen, W. (2020). Covering Protests on Twitter: The Influences on Journalists' Social Media Portrayals of Left-and Right-Leaning Demonstrations in Brazil. The International Journal of Press/Politics, 25(2), 260-280. https://doi.org/10.1177/1940161219882653

Netzer, Y., Tenenboim-Weinblatt, K., \& Shifman, L. (2014). The construction of participation in news websites. Journalism studies, 15(5), 619-631. http://dx.doi.org/10.1080/1461670X.2014.895527

Neuberger, C., \& Nuernbergk, C. (2010). Competition, complementarity or integration? The relationship between professional and participatory media. Journalism Practice, 4(3), 319-332. https://doi.org/10.1080/17512781003642923

Newman, N., Fletcher, R., Kalogeropoulos, A., Levy, D. A. L., \& Nielsen, R. K. (2017). Reuters Institute digital news report 2017. Reuters Institute for the Study of Journalism.

Nölleke, D., Grimmer, C. G., \& Horky, T. (2017). News sources and follow-up communication. Journalism Practice, 11(4), 509-526. https://doi.org/10.1080/17512786.2015.1125761

Palacio-Llanos, L. (2018). Informe Anual de la Profesión Periodística. Asociación de la Prensa de Madrid, APM. https://www.apmadrid.es/publicaciones/informe-anual-de-la-profesion/

Parmelee, J. H. (2013). Political journalists and Twitter: Influences on norms and practices. Journal of Media Practice, 14(4), 291-305. https://doi.org/10.1386/jmpr.14.4.291_1

Paulussen, S., \& Harder, R. A. (2014). Social media references in newspapers: Facebook, Twitter and YouTube as sources in newspaper journalism. Journalism practice, 8(5), 542-551. https://doi.org/10.1080/17512786.2014.894327

Paulussen, S., \& Harder, R. (2014). Social media references in newspapers. Journalism Practice, 8(5), 542-551. https://doi.org/10.1080/17512786.2014.894327

Peña-Fernández, S., Lazkano-Arrillaga, I., \& García-González, D. (2016). European newspapers' digital transition: New products and new audiences. Comunicar, 46, 27-36. https://doi.org/10.3916/C46-2016-03

Pérez-Dasilva, J. A., Larrondo, A., Mendiguren, T., Meso, K., \& Peña, S. (2021). Perfiles digitales de los periodistas vascos y diálogo con las audiencias. Universidad del País Vasco.

Pérez-Díaz, P.; Zamora-Medina, R.; \& Arroyas-Langa, E. (2020). Between Self-Regulation and Participatory Monitoring: Comparing Digital News Media Accountability Practices in Spain. Media and Communication, 8(2), 112-123. http://dx.doi.org/10.17645/mac.v8i2.2721

Peters, C., \& Witschge, T. (2015). From grand narratives of democracy to small expectations of participation. Journalism practice, 9(1). http://dx.doi.org/10.1080/17512786.2014.928455

Picone, I., De Wolf, R., \& Robijt, S. (2016). Who shares what with whom and why? Digital journalism, 4(7), 921-932. https://doi.org/10.1080/21670811.2016.1168708 
Powers, M., \& Vera-Zambrano, S. (2018). How journalists use social media in France and the United States: Analyzing technology use across journalistic fields. New Media \& Society, 20(8), 2728-2744. https://doi.org/10.1177/1461444817731566

Rauchfleisch, A., Artho, X., Metag, J., Post, S., \& Schäfer, M.S. (2017). How journalists verify user-generated content during terrorist crises. Analyzing Twitter communication during the Brussels attacks. Social Media + Society, 3(3), 1-13. https://doi.org/10.1177/2056305117717888

Reinemann, C. (2008). Journalist group dynamics. In W. Donsbach (Ed.), The International Encyclopedia of Communication (pp. 2573-2579). Blackwell.

Roberts, C., \& Emmons, B. (2016). Twitter in the press box: How a new technology affects game-day routines of print-focused sports journalists. International Journal of Sport Communication, 9(1), 97-115. https://doi.org/10.1123/ijsc.2015-0113

Shoemaker, P. J., \& Reese, S. D. (1996). Mediating the Message: Theories of Influences on Mass Media Content. Longman.

Singer, J. B. (2010). Quality control. Journalism practice, 4(2), 127-142. http://dx.doi.org/10.1080/17512780903391979

Singer, J. B. (2013). User-Generated Visibility: Secondary Gatekeeping in a Shared Media Space. New Media E Society, 16(1), 55-73. http://doi.org/10.1177/1461444813477833

Singer, J. B., Domingo, D., Heinonen, A.; Hermida, A., Paulussen, S., Quandt, T., Reich, Z., \& Vujnovic, M. (2011). Participatory Journalism: Guarding Open Gates at Online Newspapers. New John Wiley \& Sons.

Somaiya, R. (2014). How Facebook is changing the way its users consume journalism. The New York Times.

Suárez-Villegas, J. C. (2017). Citizen Journalism. Analysis of opinions of journalists from Spain, Italy and Belgium. Convergencia, 24(74), 91-111. https://doi.org/10.29101/crcs.v0i74.4383

Suau, J. (2015). Citizens and online media participation: attitudes and motivations towards participatory journalism [Doctoral dissertation, Universitat Ramon Llull]. Universitat Ramon Llull. http://www.tesisenred.net/handle/10803/289347

Swasy, A. (2016). How journalists use Twitter: The changing landscape of US newsrooms. Lexington Books.

Tandoc, E. C. (2014). Journalism is twerking? How web analytics is changing the process of gatekeeping. New media $\mathcal{E}$ society, 16(4), 559-575. https://doi.org/10.1177/1461444814530541

Vázquez-Herrero, J., Direito-Rebollal, S., \& López-García, X. (2019). Ephemeral journalism: News distribution through Instagram stories. Social Media+ Society, 5(4), 1-13. https://doi.org/10.1177/2056305119888657

Vis, F. (2013). Twitter as a reporting tool for breaking news: Journalists tweeting the 2011 UK riots. Digital journalism, 1(1), 27-47. https://doi.org/10.1080/21670811.2012.741316

Von-Nordheim, G., Boczek, K., \& Koppers, L. (2018). Sourcing the sources: An analysis of the use of Twitter and Facebook as a journalistic source over 10 years in The New York Times, The Guardian, and Süddeutsche Zeitung. Digital journalism, 6(7), 807-828. https://doi.org/10.1080/21670811.2018.1490658

Vos, T. P., \& Ferrucci, P. (2018). Who am I? Perceptions of Digital Journalists' Professional Identity. In S. A. Eldridge \& B. Franklin (Eds.), The Routledge Handbook of Developments in Digital Journalism Studies (pp. 40-52). Routledge. https://doi.org/10.4324/9781315270449

Vujnovic, M., Singer, J. B., Paulussen, S., Heinonen, A., Reich, Z., Quandt, T., Hermida, A., \& Domingo, D. (2010). Exploring the political-economic factors of participatory journalism: Views of online journalists in 10 countries. Journalism Practice, 4(3), 285-296. https://doi.org/10.1080/17512781003640588 
Wardle, C., \& Williams, A. (2010). Beyond user-generated content: a production study examining the ways in which UGC is used at the BBC. Media, culture $\mathcal{E}$ society, 32(1), 781-799. http://dx.doi.org/10.1177/0163443710373953

Weaver, D. H., \& Willnat, L. (2016). Changes in US journalism: How do journalists think about social media? Journalism Practice, 10(7), 844-855. https://doi.org/10.1080/17512786.2016.1171162

Weaver, D. H., Willnat, L., \& Wilhoit, G. C. (2019). The American Journalist in the Digital Age: Another Look at U.S. News People. Journalism $\mathcal{E}$ Mass Communication Quarterly, 96(1), 101-130. https://doi.org/10.1177/1077699018778242

\section{(c) (i) $\odot$}

(C) Attribution-NonCommercial-NoDerivatives 4.0 International (CC BY-NC-ND 4.0) https://creativecommons.org/licenses/by-nc-nd/4.0/ 